Рекомендована д. фрармац. наук, профр. Д. І. Дмитрієвським

УДК 615.2;614.27

DOI 10.11603/2312-0967.2017.2.7902

\title{
ТРАНСДЕРМАЛЬНІ СИСТЕМИ ДОСТАВКИ ЛІКАРСЬКИХ РЕЧОВИН
}

\author{
() Б. В. Вонс, М. Б. Чубка, Т. А. Грошовий
}

ДВНЗ «Тернопільський державний медичний університет імені І. Я. Горбачевського МО3 України»

bohdana.vons@gmail.com

\begin{abstract}
Мета роботи. Узагальнити дані літературних джерел щодо переваг та недоліків, класифрікації, особливостей технології трансдермальних терапевтичних систем.

Матеріали і методи. У роботі використано методи інфрормаційного пошуку, аналізу даних літератури щодо трансдермальних систем та перспектив їх використання у медичній практиці.

Результати й обговорення. Трансдермальні терапевтичні системи доставки лікарських речовин успішно розвиваються як альтернатива системному введенню речовин та являють собою препарати, які наносяться на поверхню тіла і призначені для доставки певної дози активного фрармацевтичного інгредієнта через шар шкіри безпосередньо в кров'яне русло або ж сприяють загоєнню травмованої ділянки тіла. Усі трансдермальні системи класифікують за трьома поколіннями розвитку. Залежно від методу введення лікарських речовин в систему, вони поділяються на три категорії: системи матричного, резервуарного та мікрорезервуарного типів.

Висновки. Переваги таких лікарських засобів та позитивні рішення впровадження розробок трансдермальних терапевтичних систем у промислове виробництво активізували науково-дослідницьку діяльність у даному напрямку.
\end{abstract}

Ключові слова: трансдермальна терапевтична система; трансдермальний пластир; активний орармацевтичний інгредієнт; лікарська речовина.

Вступ. За останні три десятиліття розробка контрольованих систем доставки лікарських речовин (ЛР) набуває все більшого значення у фрармацевтичній технології. Трансдермальний шлях є одним 3 найбільш перспективних методів доставки активних речовин через шкіру в велике коло кровообігу, що забезпечує зручний спосіб введення при різних клінічних показаннях. У науковій літературі можна зустріти «перехрещення» визначень «трансдермальна терапевтична система» (ТТС) і «трансдермальний пластир», оскільки за змістом вони є однаковими, лише конкретизується орорма ТТС.

Трансдермальні терапевтичні системи призначені для доставки активного фрармацевтичного інгредієнта (АФІ) через шкіру для досягнення системного ефекту ЛР та відрізняються від традиційної місцевої терапії. Принцип дії ТТС полягає в транспорті АФІ через шкіру завдяки пасивній дифузії, в результаті якої за рахунок зміни градієнта концентрації АФІ дифундує 3 матриці або дифузійного середовища і проникає в організм людини $[1,2]$. Принцип вивільнення АФІ із ТТС та потрапляння його у кров'яне русло складається з трьох етапів, які проходять через певні періоди часу один за одним. Перший етап характеризується зростанням концентрації АФІ у крові, що трохи перевищує мінімальну терапевтичну концентрацію, але не досягає рівня токсичної. На другому етапі концентрація АФІ у крові врівноважується до необхідного рівня для забезпечення терапевтичного ефекту. Третій етап $€$ завершальним, а саме, режим подачі АФІ закінчується та його рівень починає знижуватись до нуля. Остання ділянка може бути скорочена за часом при видаленні ТТС зі шкіри, у такому випадку надходження АФІ припиняється миттєво [1-4].

Першою системою трансдермальної доставки ЛР був триденний пластир із скополаміном (Transderm $\mathrm{Scop}()$, схвалений в 1979 р. Управлінням з санітарного нагляду за якістю харчових продуктів та медикаментів у США (Food and Drug Administration, FDA) та призначений для профрілактики нудоти і блювання, пов'язаних із поїздками, особливо морським шляхом [6].

До трансдермальних систем належать нашкірні смужки з вивільненням активних речовин впродовж 7 днів, нашкірні системи “Azone”, системи з пульсаційною подачею ЛР [5].

Промислове виробництво ТТС зростає у всьому світі. Наприклад, представляючи більш ніж 12 \% світової торгівлі ЛЗ у 2010 р., цей ринок був оцінений в 21,5 млрд доларів, і, як очікувалось, досягнув 31,5 млрд доларів США у 2015 році [7]. Постійно оновлений перелік ТТС, зареєстрованих у США, наведений на офріційному сайті Управління з санітарного

ISSN 2312-0967. Фармацевтичний часопис. 2017. № 2 
нагляду за якістю харчових продуктів та медикаментів США (FDA) [8]. За оцінками, більше одного мільярда трансдермальних пластирів на даний час виробляється щороку. Перелік ТТС, які зареєстровані в Україні, можна переглянути на сайті Нормативно-директивні документи Міністерства охорони здоров'я України [9].

Трансдермальні системи доставки ЛР мають ряд переваг порівняно з традиційними лікарськими формами і пероральними системами контрольованої доставки АФІ. Зокрема, такі системи забезпечують більш швидку дію діючих речовин; уникнення ефекту першої прохідності печінки і шлункового метаболізму; легкість швидкої ідентифрікації лР в надзвичайних ситуаціях; контроль за швидкістю проникнення препарату через шкіру; можливість постійно підтримувати концентрацію АФІ в крові; при необхідності зменшення дози ЛР; зведення до мінімуму або повне усунення місцевих та системних побічних есректів; отримання меншого ефекту потенціювання або послаблення фрармакологічної дії препарату при тривалому застосуванні; можливість зниження частоти введення призначеного ЛЗ у зв'язку з пролонгованою дією (від 1 до 7 днів); зручність і простоту в застосуванні $[10,11]$.

ТТС також мають переваги порівняно з ін'єкційними засобами, введення яких є болючим, при застосуванні таких ЛЗ назбируються небезпечні відходи і відповідно створюється певний ризик передачі захворювання голкою повторного використання [12].

Проте потрібно визнати, окрім переваг, дані ЛФ мають і певні недоліки, серед яких подразнення шкіри, що може зумовити появу алергічних реакцій; обмежений перелік АФІ, які можна використовувати для розробки ТТС. Найбільш перспективними для успішної трансдермальної доставки є речовини, що мають високу розчинність як у воді, так і в ліпідах, оскільки багато АФІ, особливо з гідрофрільними структурами, проникають крізь шкіру занадто повільно, тому не можуть досягти терапевтичного рівня, а речовини 3 молекулярною масою понад 3000 г/моль не можуть пройти епідермальний бар'єр шкіри та потрапити в кров'яне русло $[13,14]$.

При призначенні ТТС необхідно врахувати не лише фрізико-хімічні властивості АФІ, але й фрізіологічний стан поверхні шкіри (ступінь пошкодження рогового шару, запальні зміни, інтенсивність кровопостачання, вікові відмінності тощо).

ТТС можуть застосовуватись для лікування захворювань шкіри або в системній терапії грибкових захворювань нігтів, алопеції, хронічного обструктивного захворювання легень, ВІЛ/СНІДу, хвороб Паркінсона та Альцгеймера, захворювань опорно-рухового апарату та серцево-судинних патологій, при гормональних, неврологічних і психічних розладах, при лікуванні тютюнової залежності, а також як протигрипозні препарати та засоби контрацепції $[15,16]$.
3 метою забезпечення максимальної доступності діючих речовин та мінімізації дози залежно від ефекту препарату впродовж останніх 30-ти років проводились дослідження щодо вивчення доставки АФІ в конкретний орган тіла (легені, печінка, серце тощо).

На міжнародному фрармацевтичному ринку існують такі категорії ТТС: системи на основі напівпроникних мембран (“Трансдерм-нітро-ТТС” $з$ нітрогліцерином); полідисперсні системи на основі адгезивів, що насичені ЛР («Франдол» - система 3 ізосорбіт динітратом); дисперсні системи на основі полімерних некогезійних матриць, які забезпечують задану швидкість дифузії і коригують вивільнення АФІ за рахунок створення в резервуарі градієнта їх концентрації («Нітро-Дур» з нітрогліцерином); полідисперсні системи, в яких мікрорезервуари дисперговані у ліпофрільному полімері (мікрорезервуарна система «Нiтродиск» 3 нітрогліцерином) та інші $[5,7,8]$.

Також була вивчена та доведена необхідність використання тонких полімерних мембран для трансдермальної системи доставки Л3 [17]. Полімери $€$ основою ТТС, які контролюють вивільнення АФІ 3 лікарської фрорми. Полімерна матриця може бути отримана шляхом диспергування в рідкому або твердому стані синтетичної полімерної основи. Крім того, вони повинні забезпечувати терапевтичну ефективність ЛЗ за період, впродовж якого очікується вивільнення АФІ 3 ЛФ [18]. В технології виготовлення ТТС використовують такі групи полімерів: природні полімери (похідні целюлози, желатин, шелак, віск, смоли, хітозан та інші); синтетичні полімери (полівініловий спирт, полівінілхлорид, поліетилен, поліпропілен, поліакрилати, поліаміди, сечовина, полівінілпіролідон, поліметилметакрилат тощо); синтетичні еластомери (полібутадієн, ізобутилен, нітрил, акрилонітрил, неопрен, бутилкаучук тощо) [19, 20].

Звісно, створення та розробка нових трансдермальних систем зумовлює виникнення ряду запитань щодо визначення оптимального місця розташування пластиру на тілі, встановлення біодоступності, визначення тривалості використання та контролю за есрективністю.

Прогрес у галузі трансдермальних систем доставки ліків може бути класифрікований на три покоління розвитку.

Більшість трансдермальних пластирів, які сьогодні використовують у клінічній практиці, належать до першого покоління розвитку ТТС. АФІ, які використовуються в таких системах даного покоління, повинні мати невелику молекулярну масу, бути ліпофрільними і ефрективними при низьких дозах використання [10]. Різновидом традиційної трансдермальної системи доставки першого покоління може бути рідкий спрей, гель або інші актуальні композиції на шкіру, активні речовини яких можуть в невеликій кількості транспортуватись в ороговілий шар шкіри, що відіграє роль резервуара АФІ для пролонгованого погодинно-

ISSN 2312-0967. Pharmaceutical review. 2017. № 2 
го його вивільнення в життєздатний епідерміс [21, 22]. Наприклад, гелі з тестостероном використовуються вже протягом декількох років, нещодавно схвалено трансдермальний спрей для доставки естрадіолу.

ТТС другого покоління розвитку ґрунтуються на використанні в технології методів та способів підвищення проникності шкіри, захищаючи глибокі тканини від пошкодження, що сприятиме розширенню сорери застосування трансдермальних препаратів [10]. Методами підвищення проникності АФІ через шкіру, що застосовуються при створенні ТТС даного покоління, є використання хімічних підсилювачів, застосування іонофорезу, електрофрорезу і некавітаційного ультразвуку (сонофорез).

Встановлено, що підвищувати проникну активність шкіри може ряд хімічних агентів, зокрема, спирти, естери, гліколі, жирні кислоти, піролідон, сульфоксиди, терпени, аніонні, катіонні та неіоногенні поверхнево активні речовини [23].

Впродовж багатьох років іонофорез вивчався як комплексна дія на організм гальванічного струму та лікарського препарату. Гальванічний струм зміцнює стінки судин і покращує всі метаболічні процеси в тканинах. Струм допомагає активним компонентам Л3 при транспортуванні зарядженої молекули проникнути крізь шкіру, тоді активні речовини починають працювати безпосередньо в тканинах у фрормі концентрованої маси іонів. У даний час проводиться багато досліджень щодо вивчення можливостей використання цієї методики для доставки молекул з великою молекулярною масою [10, 24]. Перевагами застосування іонофрорезу є можливість уникнення ризику інорікування; контрольоване вивільнення АФІ 3 ЛФ, завдяки регулюванню сили струму; безболісність та зменшення побічних ефектів діючих речовин.

Некавітаційний ультразвук (сонофорез) було вперше широко визнано як підсилювач проникності речовин через шкіру, коли фізіотерапевти виявили, що втирання нестероїдних протизапальних засобів в шкіру під дією ультразвуку, підвищує їх ефективність. Передбачається, що ультразвук, порушуючи структуру рогового шару ліпідів і тим самим збільшуючи його проникність, допомагає ЛР глибше проникнути в тканини. Градієнти тиску та коливання, пов'язані з ультразвуком, виступають як рушійна сила для переміщення АФІ через шкіру в тканини [25].

Дія електрофрорезу поєднує вплив постійного струму, зазвичай гальванічного, який підвищує чутливість тканин до дії ліків, та невеликої кількості АФІ. За рахунок дуже малої швидкості переміщення іонів, великого опору епідермісу, обмеження тривалості проведення процедури та сили струму іони діючої речовини проникають лише в епідерміс, утворюючи в ньому своєрідне депо, з якого поступово вимиваються крово- і лімфротоком, у зв'язку з чим розраховувати на швидкий ефект АФІ не потрібно [10].
Принцип дії ТТС третього покоління полягає в руйнуванні рогового шару шкіри і тим самим досягається більш ефрективна трансдермальна доставка АФІ, захищаючи при цьому глибокі тканини [10]. Для покращення технологічних характеристик ТТС даного покоління використовують комбінації хімічних підсилювачів, кавітаційний ультразвук, теплову абляцію, мікродермбразію, трансдермальні пластири з мікроголками.

На сьогодні, вже досліджено близько 500 різних поєднань хімічних підсилювачів та сфрормовано більше 5000 композицій, які широко використовуються у технології ТТС.

Теплова абляція $є$ складним процесом, що полягає в передачі тепла до поверхні шкіри, при цьому покращується транспорт речовин з поверхні твердого тіла під впливом випромінювання чи потоку гарячого газу [10].

Мікродермабразія є механічним пілінгом, для виконання якого використовуються мікрокристали, які під натиском передаються через наконечник і видаляють верхній шар відмерлих клітин шкіри, що сприяє проникненню АФІ в глибокі шари шкіри [26, 27].

Мікроголки, які використовуються в технології трансдермальних пластирів, є досить довгими, щоб проникнути через зовнішній шар шкіри, але досить малими, щоб викликати больові відчуття. На сьогодні вже розроблені мікроголки з водорозчинних полімерів, що інкапсулюють різні сполуки всередині матриксу голки [28]. Ці мікроголки розчиняються в шкірі впродовж декількох хвилин, не залишаючи ніяких гострих медичних відходів після використання [29, 30]. Прогресуючого розвитку набули трансдермальні пластирі 3 мікроголками та розробки з використанням термічної абляції, які на даний час знаходяться на стадії клінічних випробувань.

На сьогодні вдосконалені ТТС другого і третього покоління стають перспективною ЛФ для практичного застосування у медицині всього світу [10, 30].

Незважаючи на те, що трансдермальні системи класифрікують по-різному, трансдермальні пластирі можуть бути розділені на три основні категорії відповідно до того, як АФІ вводиться в систему доставки [31-36] (рис. 1).

1. Резервуар-система являє собою резервуар з діючою речовиною, яка розміщена між шаром пластиру та мембраною, яка контролює вивільнення АФІ із системи та може бути мікропористою або непроникною. У резервуарі для ЛР препарат може бути у вигляді розчину, суспензії, гелю або диспергованим в матриці твердого полімеру. На зовнішній поверхні резервуар-системи використовують тонкий шар полімеру [31].

2. Матричний тип ТТС поділяється на:

а) ЛЗ в клейовій системі. Резервуар з лікарським засобом отримують диспергуванням АФІ в липкому полімері із подальшим розміщенням такого шару по-

ISSN 2312-0967. Фармацевтичний часопис. 2017. № 2 


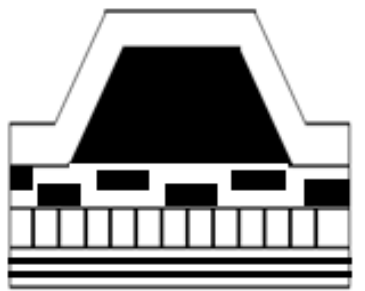

TTC резервуарного типу

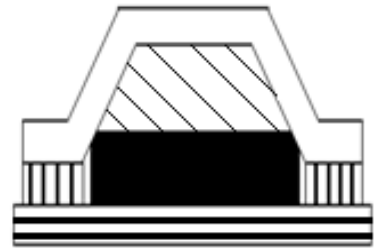

ТТС клейового типу $з$ АФІ

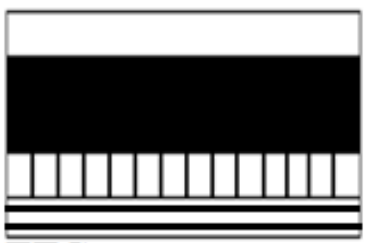

TTC

1.

2.

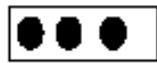

3.

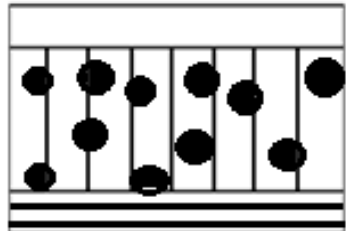

ТТС мікрорезервуарного

типу
4.

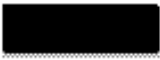

5.

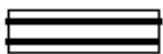

6.

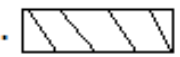

Рис. 1. Схематичне зображення ТТС: 1 - покривна плівка (підкладка); 2 - контроль за вивільненням АФІ; 3 адгезійний шар; 4 - резервуар з АФІ; 5 - захисна плівка; 6 - опорно-захисна мембрана.

лімеру на непроникній захисній основі. У верхній частині резервуара використовують шар твердого полімеру, який не містить АФІ [32, 33].

б) матрично-дисперсійна система. Препарат рівномірно диспергують у гідрофрільній або ліпофрільній полімерній матриці. Цей полімерний диск, що містить діючу речовину, фріксують на опорному диску в відсіку, який виготовляють із захисного шару, що є непроникним для АФІ [34].

3. Мікрорезервуар-система. Ця система доставки являє собою комбінацію резервуарної і матрично-дисперсної систем. Спочатку утворюється резервуар із ЛР шляхом суспендування її в водному розчині водорозчинного полімеру, а потім проводиться диспергування гомогенного розчину в ліпофрільному полімері з утворенням тисячі мікроскопічних ссрер з АФІ [35].

У цілому, ТТС складаються 3 наступних основних частин: покривна плівка (підкладка), яка механічно скріплює увесь пристрій і перешкоджає дисрузії АФІ у напрямку, протилежному шкірі; адгезійний шар, який $€$ чутливим до дії тиску та необхідний для прикрі- плення ТТС до шкіри; резервуар з АФІ; захисна плівка для захисту липкого шару і перешкоджання дисрузії АФІ із ТТС до її аплікації на шкірі. У ТТС матричнодисперсійного типу в конструкцію додана мембрана, що обмежує потік АФІ із резервуара. При аплікації ТТС покриття відділяється, система щільно притискається до шкіри і залишається на ній впродовж усього часу подачі АФІ до організму [32-34, 36].

Висновок. В останні роки трансдермальні системи доставки ЛР набувають великого значення та в майбутньому можуть стати одними із найкращих новітніх систем доставки АФІ. ТТС мають потенційні переваги, а наукові і технологічні досягнення, які вже впроваджені, створюють якісно новий рівень можливостей для доставки діючих речовин. 3 метою збільшення можливостей застосування ТТС сьогодні досліджується багато нових підходів щодо подолання бар'єрних властивостей шкіри, актуальним залишається вивчення можливостей коригування проникності діючих речовин, коли б вона могла бути оборотною, передбачуваною і контрольованою.

\section{ТРАНСДЕРМАЛЬНЫЕ СИСТЕМЫ ДОСТАВКИ ЛЕКАРСТВЕННЫХ ВЕЩЕСТВ}

\section{Б. В. Вонс, М. Б. Чубка, Т. А. Грошовый}

ГВУЗ «Тернопольский государственный медицинский университет имени И. Я. Горбачевского МЗ Украины» bohdana.vons@gmail.com

Цель работы. Обобщить данные литературных источников относительно преимуществ и недостатков, классификации, особенностей технологии трансдермальных терапевтических систем.

Материалы и методы. В работе использованы методы информационного поиска, анализа данных литературы по трансдермальных системах и перспективах их использования в медицинской практике.

ISSN 2312-0967. Pharmaceutical review. 2017. № 2 
Результаты и обсуждение. Трансдермальные терапевтические системы доставки лекарственных веществ успешно развиваются как альтернатива системной доставке лекарств и представляют собой препараты, которые наносятся на поверхность тела и предназначены для доставки определенной дозы активного фармацевтического ингредиента сквозь слой кожи непосредственно в кровяное русло или же способствуют заживлению травмированной области тела. Все трансдермальные системы классисицируют по трем поколениями развития. В зависимости от метода введения лекарственных веществ в систему, они делятся на три категории: системы матричного, резервуарного и микрорезервуарного типов.

Выводы. Преимущества таких лекарственных средств и положительные решения внедрения разработок трансдермальных терапевтических систем в промышленное производство активизировали научноисследовательскую деятельность в данном направлении.

Ключевые слова: трансдермальная терапевтическая система; трансдермальный пластырь; действующее вещество; лекарственное вещество.

\section{TRANSDERMAL DRUG DELIVERY SYSTEM}

\section{B. V. Vons, M. B. Chubka, T. A. Hroshovyi}

\section{Horbachevsky Ternopil State Medical University \\ bohdana.vons@gmail.com}

The aim of the work. Summarizing the data of the literature on the benefits and drawbacks, classification, technology features of the transdermal therapeutic systems.

Materials and Methods. We used the methods of information retrieval and analysis of the literature about transdermal systems and the prospects for their use in clinical practice.

Results and Discussion. Transdermal therapeutic delivery systems of drugs successfully developed as an alternative delivery system of drugs and are drugs that are applied on the surface of the body and intended for delivery of a dose of the active pharmaceutical ingredient through the skin layer directly into the bloodstream or can promote healing of the injured area of the body. All transdermal systems are classified into three generations of development. Depending on the input of the drugs in to the system, they are divided into three categories: matrix diffusion controlled systems, reservoir and micro reservoir types.

Conclusions. The advantages of such medications and positive decisions of implementing development transdermal therapeutic systems in the industrial production is intensified in research and development in this direction.

Key words: transdermal therapeutic system; transdermal patch; the active pharmaceutical ingredient; dosage form.

\section{Список літератури}

1. Prausnitz M. Transdermal drug delivery / M. Prausnitz, R. Langer // 1. Nat Biotechnol. - 2008. - Vol. 26, Is. 11. P. 1261-1268.

2. Львова Л. В. Трансдермальные терапевтические системы / Л. В. Львова // Провизор. - 2004. - № 17. C. 26-29.

3. Kumar R. Modified Transdermal Technologies: Breaking the Barriers of Drug Permeation via the Skin / R. Kumar, A. Philip // Trop. J. Pharm. Res. - 2007. - Vol. 6, Is. 1. P. 633-644.

4. Transdermal drug delivery system: a review / D. Patel, S. A. Chaudhary, B. Parma [et al.] // The pharma innovation [electronic resource]. - 2012. - Vol. 1, Is. 4. - P. 66-75. 5. Ansel's pharmaceutical dosage forms and drug delivery systems / V. Loyd Allen, G. Popovich Nicholas, C. Ansel Howard. - Philadelphia: Wolter Kluwer Publishers, 2005. 9th Edition. - 710 p.

6. Перцев І. М. Допоміжні речовини - 5. Створення новітніх ліків (терапевтичних систем) / І. М. Перцев, О. А. Рубан // Еженедельник аптека. - [Електронний ресурс] / - Режим доступу до інфрормації: http://www.ap- teka.ua/article/322026

7. Sakalle P. Design, evaluation, parameters and marketed products of transdermal patches: a review / P. Sakalle, S. Dwivedi, A. Dwivedi // Journal of Pharmacy Research. 2010. - Vol. (2). - P. 235-240.

8. Сайт Управлінням 3 санітарного нагляду за якістю харчових продуктів та медикаментів в США [Електронний ресурс]. - Режим доступу до інформації: 8. www.fda.gov/cvm/FOI.

9. Нормативно-директивні документи МОЗ України [Електронний ресурс]. / Міністерство охорони здоров'я України - Режим доступу до інфоомації: http://mozdocs. kiev.ua

10. Prausnitz M. R. Current status and future potential of transdermal drug delivery / M. R. Prausnitz, S. Mitragotri, R. Langer // Nat. Rev. Drug Discov. - 2004. - Vol. 3. P. 115-124.

11. Enhanced transdermal drug delivery techniques: an extensive review on patents / M. Rizwan, M. Aqil, S. Talegoankar [et al.] // Recent Pat Drug Deliv\&formul. - 2009. - Vol. 3 (2). - P. 105-124.

ISSN 2312-0967. Фармацевтичний часопис. 2017. № 2 
12. Transdermal drug delivery system: an overview / J. Ashok Kumar, N. Pullakandam, S. Lakshmana [et al.] // International Journal of Pharmaceutical Sciences Review and Research. - Vol. 3, Is. 2. - P. 49-54.

13. Prausnitz M. R. Current status and future potential of transdermal drug delivery / M. R. Prausnitz, S. Mitragotri, R. Langer // Nat. Rev. Drug Discov. - 2004. - Vol. 3. P. $115-124$.

14. Кравченко И. А. Трансдермальное введение лекарственных препаратов / И. А. Кравченко. - Одесса : Астропринт, 2001. - 166 с.

15. A statistical approach to the development of a transdermal delivery system for ondansetron / Y. Obata, Y. Ashitakaa, S. Kikuchia [et al.] // International Int. J. Pharm. 2010. - 399. - P. 87-93.

16. Nortriptyline Hydrochoride skin absorption: development of a transdermal patch / A. Melero, T. M. Garrigues, P. Almudever [et al.] // Eur. J. Pharm. Biopharm. - 2008. Vol. 69. - P. 588-596.

17. A review: transdermal drug delivery system: a tool for novel drug delivery system / Sharma Nikhil, Agarwal Geta, A. C. Rana [et al.] // International Journal of Drug Development and Research. - 2011. - Vol. 3, Is. 3. - P. 113-116. 18. Transdermal drug delivery systems: an overview / L. Latheeshjlal, P. Phanitejaswini, Y.Soujanya [et al.] // IJPRIF. - 2011. - Vol. 3, Is. 4. - P. 2140-2148.

19. Dendrimers: Emerging polymers for drugdelivery systems / Basavaraj K. Nanjwadea, Hiren M. Bechraa, Ganesh K.19. Derkar [et al.] // Eur. J. Pharm. Sci. - 2009. - Vol. 38, Is. 3. - P. 185-196.

20. Recent approaches in transdermal drug delivery system / Debjit Bhowmik, K. Rao. Pusupoleti, S. Duraivel [et al.] // The Pharma Innovation Journal. - 2013. - Vol. 2, Is. 3. - P. 99-108.

21. Foldvari M. DNA delivery for vaccination and therapeutics through the skin / M. Foldvari, S. Babiuk, I. Badea // Curr. Drug Deliv. - 2006. - Vol. 3. - P. 17-28.

22. Glenn G. M. Mass vaccination: solutions in the skin / G. M. Glenn, R. T. Kenney // Curr. Top. Microbiol. Immunol. - 2006. - Vol. 3. - P. 247-268.

23. Chemical penetration enhancers: for transdermal drug delivery systems / Saurabh Vinod Raut, Lalita S. Nemade, Maya T. Desai [et al.] // International Journal of Pharmacy Review and Research. - 2014. - Vol. 4, Is. 1. - P. 33-40.

24. Qiuxi Fan. Iontophoretic transdermal drug delivery sys-

\section{References}

1. Prausnitz MR, Langer R. Transdermal drug delivery. Nat Biotechnol. 2008;26(11):1261-8. Available from: doi: 10.1038/nbt.1504

2. Lvova L.V. [Transdermal therapeutic systems]. Provizor. 2004;17: 26-29. Ukrainian.

3. Kumar R, Philip A. Modified transdermal technologies: breaking the barriers of drug permeation via the skin. Trop J Pharm Res. 2007;6(1): 633-644.

4. Patel D, Chaudhary SA, Parma B, Bhura N. Transdermal drug delivery system: a review. The pharma innovation [electronic resource]. 2012;1(4):66-75. Available from: http://www. thepharmajournal.com/vol1Issue4/Issue_june_2012/14.pdf tem using a conducting polymeric membrane / Qiuxi Fan, Kamalesh K. Sirkar, Bozena Michniak // J. Membr. Sci. 2008. - Vol. 321. - P. 240-249.

Ita K. Transdermal Delivery of Drugs with Microneedles Potential and Challenges / K. 25. Ita // 25. Pharmaceutics. - 2015. - Vol. 7, Is. 3. - P. 90-105.

26. Transdermal microconduits by microscission for drug delivery and sample acquisition / T. O. Herndon, S. Gonzalez, T. Gowrishankar [et al.] // BMC Med. -2004. - Vol. 2. - P. 2-12. 27. Transcutaneous immunization with heat-labile enterotoxin: development of a needle-free vaccine patch / G. M. Glenn, D. C. Flyer, L. R. Ellingsworth [et al.] // Expert Rev. Vaccines. - 2007. - Vol. 6. - P. 809-819.

28. Modified Release Drug Delivery. In: Rathbone / M. R. Prausnitz, H. S. Gill, Jh. M. J. Park [et al.]. - New York: Informa Healthcare, 2008. - 405 p.

29. Gill H. S. Coated microneedles for transdermal delivery / H. S. Gill, M. R. Prausnitz // J. Control. Release . - 2007. - Vol. 117. - P. 227-237.

30. Lee J. W. Dissolving microneedles for transdermal drug delivery / J. W. Lee, J. H. Park, M. R. Prausnitz // Biomaterials. - 2008. - Vol. 29, Is. 13. - P. 2113-2124.

31. Wolff H. M. Optimal process design for the manufacturing of transdermal drug delivery systems / H. M. Wolff // PSTT. - 2000. - Vol. 3 (5). - P. 173-181.

32. Responsive polymers in controlled drug delivery I A. K. Bajpai, Sandeep K. Shukla, Smitha Bhanu [et al.] // Progress in Polymer Science. - 2008. - Vol. 33, Is. 11. P. 1088-1118.

33. Transdermal drug delivery system: a review / P. K. Gaur, S. Mishra, S. Purohit [et al.] // Asian Journal of Pharmaceutical and Clinical Research. - 2009. - Vol. 2. - P. 14-20.

34. Adhesion testing of transdermal matrix patches with a probe tack test - in vitro and in vivo evaluation / E. Gutschke, S. Bracht, S. Nagel [et al.] // Eur. J. Pharm. Biopharm. - 2010. - Vol. 75, Is. 3. - P. 399-404.

35. Prausnitz M. R. Current status and future potential of transdermal drug delivery / M. R. Prausnitz, S. Mitragotri, R. Langer // Nat. Rev. Drug Discov. - 2004 - Vol. 3. P. $115-124$

36. Farahmand S. Transdermal drug pharmacokinetics in man: Interindividual variability and partial prediction I S. Farahmand, H. I. Maibach // Int. J. Pharm. - 2009. Vol. 367, Is. 1-2. - P. 1-15.

ISSN 2312-0967. Pharmaceutical review. 2017. № 2

5. Loyd VA, Jr., Popovich NG, Ansel HC. Ansel's pharmaceutical dosage forms and drug delivery systems. Philadelphia: Wolter Kluwer Publishers; 2005. 9th Edition. USA. 6. Percev IM, Ruban OA. [Additional substances - 5. Creation of modern drugs (therapeutic system)]. Shchotyzh apteka. 2015. Ukrainian. Available from: http://www.apteka. ua/article/322026

7. Sakalle P, Dwivedi S, Dwivedi A. Design, evaluation, parameters and marketed products of transdermal patches. J Pharm Res. 2010;2:235-240.

8. Sait Upravlinniam z sanitarnoho nahliadu za yakistiu kharchovykh produktiv ta medykamentiv v SShA. Available 
from: www.fda.gov/cvm/FOI.

9. Normatyvno-dyrektyvni dokumenty Ministerstva okhorony zdorovia Ukrainy. Available from: http://mozdocs.kiev.ua 10. Prausnitz MR, Mitragotri S, Langer R. Current status and future potential of transdermal drug delivery. Nat Rev Drug Discov. 2004;3:115-124.

11. Rizwan M, Aqil M, Talegaonkar S, Azeem A, Sultana $Y$, Ali A. Enhanced transdermal drug delivery techniques: an extensive review on patents. Recent Pat Drug Deliv Formul. 2009;3(2):105-24.

12. Kumar J. Ashok, Pullakandam N., Prabu S. Lakshmana, Gopal V. Transdermal drug delivery system: an overview. Int. J Pharm Sci Rev Res. 2010;3(2):49-54.

13. Prausnitz MR, Mitragotri S, Langer R. Current status and future potential of transdermal drug delivery. Nat Rev Drug Discov. 2004;3(2):115-24. Available from: DOI: 10.1038/nrd1304.

14. Kravchenko YA. Transdermal introduction of drugs. [Трансдермальное введение лекарственных препаратов] Odessa: Astroprynt; 2001. Russian.

15. Obata Y, Ashitaka Y, Kikuchi S, Isowa K, Takayama K. A statistical approach to the development of a transdermal delivery system for ondansetron. Int J Pharm. 2010; 399(1-2):87-93. Available from: doi: 10.1016/j. ijpharm.2010.08.006. Epub 2010 Aug 10.

16. Melero A, Garrigues TM, Almudever P, Villodre AM, Lehr CM, Schäfer U. Nortriptyline Hydrochoride skin absorption: development of a transdermal patch. Eur J Pharm Biopharm. 2008;69(2):588-96. Available from: doi: 10.1016/j.ejpb.2007.11.012. Epub 2007 Nov 28.

17. Sharma Nikhil, Agarwal Geta, Rana AC, Bhat Zulfiqar Ali, Kumar Dinesh. A review: transdermal drug delivery system: a tool for novel drug delivery system. Int J Drug Dev Res. 2011;3(3):113-6.

18. Latheeshjlal L, Phanitejaswini P, Soujanya Y, Swapna U, Sarika V, Moulika G. Transdermal drug delivery systems: an overview. IJPRIF. 2011;3(4):2140-8.

19. Nanjwade Basavaraj K, Bechra Hiren M, Derkar Ganesh K, Manvi FV, Nanjwade Veerendra K. Dendrimers: Emerging polymers for drugdelivery systems. Eur J Pharm Sci. 2009;38(3):185-196.

20. Bhowmik D, Pusupoleti KRao, Duraivel S, Kumar Sampath KP. Recent approaches in transdermal drug delivery system. The pharma innovation [electronic resource]. 2013;2(3):99-108.

21. Foldvari M, Babiuk S, Badea I. DNA delivery for vaccination and therapeutics through the skin. Curr Drug Deliv. 2006;3(1):17-28.

22. Glenn GM, Kenney RT. Mass vaccination: solutions in the skin. Curr Top Microbiol Immunol. 2006;304:247-68.

23. Raut Saurabh Vinod, Nemade Lalita S., Desai Maya T.,

Bonde Shailejkumar D., Dongare Shweta U. Chemical penetration enhancers: for transdermal drug delivery systems. IJPRR. 2014;4(1):33-40.

24. Fan Qiuxi, Sirkar Kamalesh, Michniak-Kohn Bozena. Iontophoretic transdermal drug delivery system using a conducting polymeric membrane. J Membr Sci. 2008;321(2):240-249.

25. Ita K. Transdermal delivery of drugs with microneedles - potential and challenge. J Pharm. 2015;7(3):90-105. Available from: doi: 10.3390/pharmaceutics7030090

26. Herndon Terry O, Gonzalez Salvador, Gowrishankar TR, Anderson Rox R, Weaver James C. Transdermal microconduits by microscission for drug delivery and sample acquisition. BMC Med. 2004;2:12. Available from: DOI: 10.1186/1741-7015-2-12

27. Glenn GM, Flyer DC, Ellingsworth LR, Frech SA, Frerichs DM, Seid RC, Yu J. Transcutaneous immunization with heat-labile enterotoxin: development of a needle-free vaccine patch. Expert Rev Vaccines. 2007;6(5):809-19. Available from: DOI: 10.1586/14760584.6.5.809

28. Prausnitz MR, Gill HS, Park JH. Modified release drug delivery. In: Rathbone MJ, Hadgraft J, Roberts MS, Lane ME. New York: Informa Healthcare; 2008.

29. Gill HS, Prausnitz MR. Coated microneedles for transdermal delivery. J Control Release. 2007;117(2):227-37. Epub 2006 Oct 24. Available from: DOI: 10.1016/j.jconrel.2006.10.017

30. Lee JW, Park JH, Prausnitz MR. Dissolving microneedles for transdermal drug delivery. Biomaterials. 2008;29(13):2113-24. Available from: doi: 10.1016/j.biomaterials.2007.12.048. Epub 2008 Feb 7.

31. Wolff HM. Optimal process design for the manufacturing of transdermal drug delivery systems. Pharm Sci Technolo Today. 2000;3(5):173-181.

32. Bajpai AK., Shukla Sandeep K, Bhanu Smitha, Kankane Sanjana. Responsive polymers in controlled drug delivery. Prog Polym Sci. 2008;33(11):1088-1118.

33. Gaur PK, Mishra S, Purohit S, Dave K. Transdermal drug delivery system - a review. AJPCR. 2009; 2:14-20.

34. Gutschke E, Bracht S, Nagel S, Weitschies W. Adhesion testing of transdermal matrix patches with a probe tack test - In vitro and in vivo evaluation. Eur. J. Pharm. Biopharm. 2010;75(3):399-404. Available from: doi.org/10.1016/j. ejpb.2010.03.016

35. Prausnitz MR, Mitragotri S, Langer R. Current status and future potential of transdermal drug delivery. Nat Rev Drug Discov. 2004;3:115-124. Available from: doi:10.1038/nrd1304

36. Farahmand S, Maibach HI. Transdermal drug pharmacokinetics in man: Interindividual variability and partial prediction. Int J Pharm. 2009;367(1-2):1-15. Available from: doi.org/10.1016/j.jpharm.2008.11.020

Отримано 19.04.2017 